\title{
Infected and ruptured retroperitoneal teratoma
}

\author{
Azura Mohamed Mukhari Shahizon, ${ }^{1}$ Faizah Mohd Zaki, ${ }^{1}$ Mohd Ramli Julian, ${ }^{1}$ \\ Mohammad Hanafiah²
}

${ }^{1}$ Department of Radiology, Universiti Kebangsaan Malaysia Medical Centre, Cheras, Kuala Lumpur, Malaysia

2Department of Radiology, MARA University of Technology Clinical Training Centre, Sungai Buloh, Selangor, Malaysia

Correspondence to Dr Mohammad Hanafiah, mhanafiah8804@gmail.com

\section{DESCRIPTION}

We present images of an infected and ruptured retroperitoneal teratoma in an 8-month-old baby girl, who presented with a 2-week history of lowgrade intermittent fever and failure to thrive. On arrival at the hospital, she was lethargic, febrile and mildly dehydrated. The abdomen was distended with a palpable mass occupying the central abdomen and the left lumbar region.

The white cell count and $\mathrm{C}$ reactive protein were elevated with measurement of $20.9 \mathrm{mg} / \mathrm{dL}$ and $6.27 \mathrm{mg} / \mathrm{dL}$, respectively, indicating an underlying infection. Both tumour markers, $\alpha$-fetoprotein $(7.56 \mathrm{ng} / \mathrm{mL})$ and $\beta$-human chorionic gonadotropin $(<1.2 \mathrm{mlU} / \mathrm{mL})$, were within normal limits. A sonographic study of the abdomen showed multiple intra-abdominal collections. The subsequent urgent abdominal CT revealed a relatively large left retroperitoneal cystic lesion with fatty and calcified components within (figure 1). The anterior wall of the lesion was disrupted and irregularly associated with multiple intraperitoneal collections. The overall appearances were compatible with a ruptured retroperitoneal teratoma.

The patient underwent an emergency laparotomy with excision of the ruptured retroperitoneal tumour and drainage of the interloop intraperitoneal collections (figure 2). The final histopathological result confirmed that the mass was a benign mature teratoma.

Retroperitoneal mature teratoma is a rare subgroup of teratoma. Tumour rupture and infection are known but rare complications of this tumour, which may result in significant morbidity if left untreated. Imaging plays an important role in the diagnosis of a mature retroperitoneal teratoma.

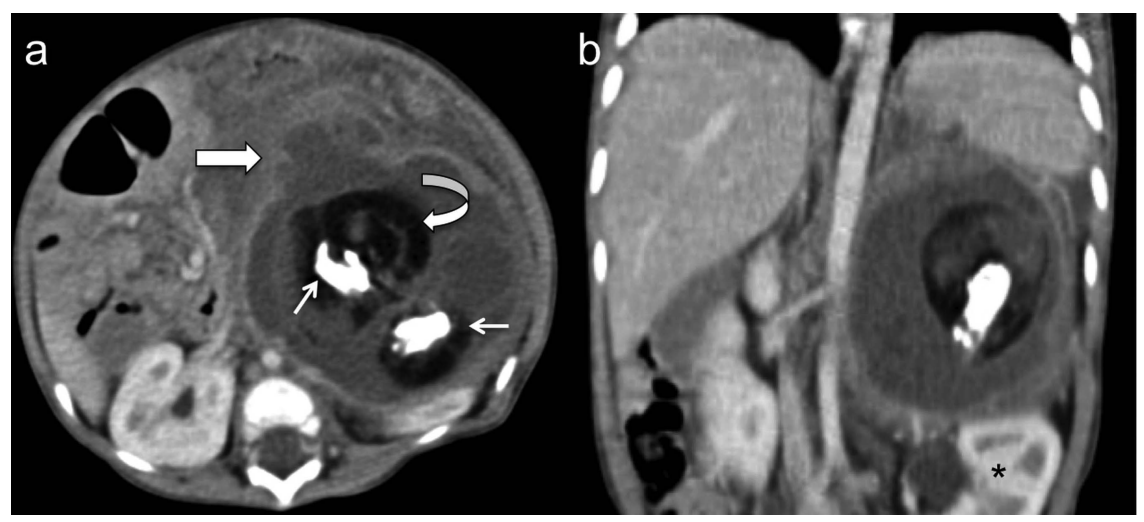

Figure 1 Images of contrast-enhanced CT of the abdomen on (A) axial and (B) coronal planes, which demonstrate the retroperitoneal teratoma in the left upper abdomen. The tumour contains fat (curved arrow) and calcification (thin arrow). The disrupted and irregular outline at the anterior aspect of the tumour indicate the site of rupture (thick arrow). The left kidney is displaced inferiorly by the mass (asterisk).

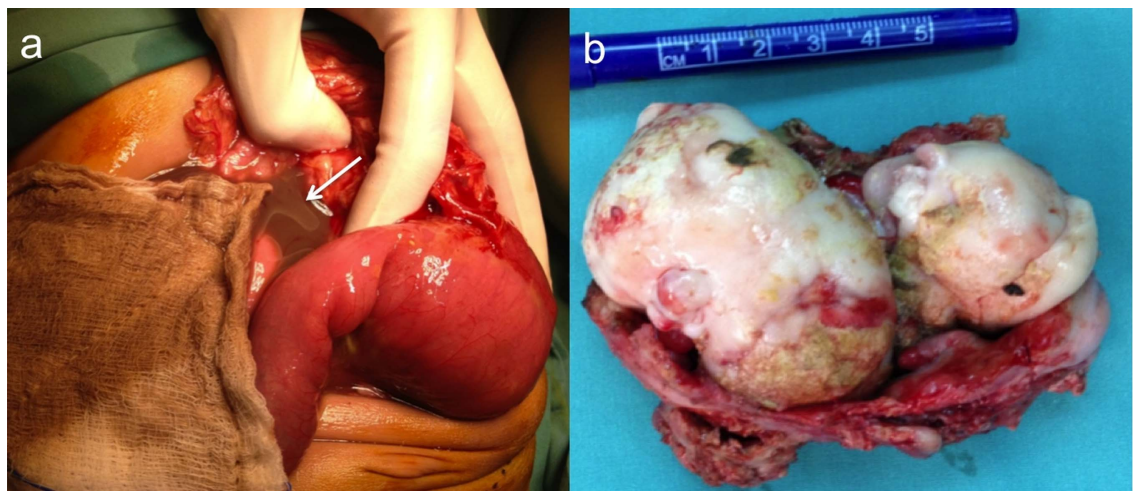

Figure 2 Images of (A) intraoperative finding of a ruptured interloop intraperitoneal collection during initial mobilisation yielding dark brownish fluid (arrow), which was subsequently drained and (B) specimen of the underlying retroperitoneal mature teratoma, containing fluid, hair, cartilaginous structures and sebaceous fluid within. 
Ultrasound is a low-risk modality, which is useful in paediatric population. However, the pitfalls of ultrasound are not capable of readily identifying calcifications, lack of anatomic resolution

\section{Learning points}

- Retroperitoneal teratoma is a rare entity and may present with complications of infection and rupture of the tumour.

- Pure benign mature teratomas should not demonstrate elevated serum tumour markers of $\alpha$-fetoprotein or $\beta$-human chorionic gonadotropin.

- Cross-sectional imaging plays an important role in preoperative diagnosis and surgical planning.

- The characteristic combination of fat, calcification and cysts suggest a mature cystic teratoma as the most appropriate preoperative diagnosis. Occasionally, teeth may be indentified within the tumour through imaging, which is a pathognomonic finding.

- Teratomas are normally well encapsulated and non-invasive to the surrounding tissues. A wall disruption with surrounding fluid or collections is suggestive of a tumour rupture. and operator dependent. ${ }^{1}$ CT scan usually reveals complex appearance of the mature teratoma with internal debris, fat attenuation and distinct calcification. In addition, CT scan may depict the precise location of the tumour and the anatomic associations with the surrounding structures, which are important information for surgical planning. ${ }^{2}$ The disadvantages of CT are the risk of radiation, risk of intravenous contrast administration and relatively longer patient preparation.

Acknowledgements The authors would like to thank the Assistant Professor Dayang Anita Aziz for providing the intraoperative and postoperative images of the tumour.

Contributors All authors had significant and equal contribution in the drafting, writing and revising of the manuscript.

Competing interests None.

Patient consent Obtained.

Provenance and peer review Not commissioned; externally peer reviewed.

\section{REFERENCES}

1 Hunter CJ, Ford HR, Extrada JJ. Alpha-fetoprotein levels correlate with the pathologic grade and surgical outcomes of pediatric retroperitoneal teratomas. Pediatr Surg Int 2009:25:331-6

2 Jonathan $\mathrm{H}$, Mazrani $\mathrm{W}$, Jones $\mathrm{N}$. Upper abdominal teratomas in infants: radiological findings and importance of the vascular anatomy. Pediatr Radiol 2008;38:750-5.

Copyright 2014 BMJ Publishing Group. All rights reserved. For permission to reuse any of this content visit http://group.bmj.com/group/rights-licensing/permissions.

BMJ Case Report Fellows may re-use this article for personal use and teaching without any further permission.

Become a Fellow of BMJ Case Reports today and you can:

- Submit as many cases as you like

- Enjoy fast sympathetic peer review and rapid publication of accepted articles

- Access all the published articles

- Re-use any of the published material for personal use and teaching without further permission

For information on Institutional Fellowships contact consortiasales@bmjgroup.com

Visit casereports.bmj.com for more articles like this and to become a Fellow 